\title{
MOTIV SLIKARJEVEGA ATELJEJA V DELIH HENRIJA MATISSA IN VPLIV NJEGOVEGA RDECEGA ATELJEJA NA SLIKARJE V DRUGI POLOVICI 20. STOLETJA
}

Ključne besede: motiv ateljeja, Henri Matisse, slikarji barvnega polja, Gabrijel Stupica, Marjan Dovjak, Bogdan Borčič

Matissov opus sta od konca sedemdesetih do začetka devetdesetih let 20. stoletja najbolj celovito raziskala John Elderfield in Jack D. Flam, ki sta opozorila na pomen nekaterih njegovih slik ateljejev. Največ pozornosti so pisci namenili Matissovemu Rdečemu ateljeju (1911, New York, The Museum of Modern Art), ki je zaradi svoje formalne radikalnosti prelomno delo evropskega modernizma. Leta 2001 je Werner Schnell objavil pomembno študijo o Rdečem ateljeju in njegovem vplivu na ameriške slikarje v drugi polovici 20. stoletja, vendar se je osredotočil le na upodobitve ateljejev brez figur. Doslej se nihče ni celovito posvetil razvoju motiva ateljeja v Matissovem opusu in le redki slovenski umetnostni zgodovinarji so se ukvarjali z vprašanjem vpliva Rdečega ateljeja na slovenske slikarje $\mathrm{v}$ drugi polovici 20. stoletja.

Glavno in najpomembnejše Matissovo izrazno sredstvo je bila barva, kar velja tudi za njegove slike ateljejev. Smisel za barve si je umetnik izoblikoval že v mladosti, saj je odraščal v mestu Bohain-en-Vermandois, ki je slovelo po razkošnih pisanih tkaninah. ${ }^{1}$ Po študiju prava v Parizu se je začel konec

1 V neposredni bližini hiše Matissovih je bilo pol ducata tkalskih ateljejev, kjer je Matisse kot otrok poslušal klopotanje čolničkov ter opazoval kretnje tkalcev pri navijanju in sukanju navitkov. Tkalci so bili dan za dnem sklonjeni nad statvami, podobno kot slikar pred slikarskim stojalom. Tako je v mladosti pridobljeni smisel za tekstil vse od začetka igral osrednjo vlogo v Matissovem slikarstvu (Spurling, 1993, 463). 
leta 1890 ali v začetku 1891 na Académie Julian v ateljeju konzervativnega salonskega slikarja Adolpha Williama Bougereauja pripravljati na sprejemne izpite na École des Beaux-Arts, vendar je bil pri prvem poskusu neuspešen. $\mathrm{Na}$ Académie Julian so od učencev zahtevali le obrtniške spretnosti ter skoraj povsem zanemarjali estetske in intelektualne sposobnosti. Poleg tega je Bougereau neprestano poniževal in zaničeval Matissa, ki je kmalu ugotovil, da v takem okolju ne bo mogel napredovati, zato je zapustil Académie Julian (Trapp, 1962-1963, 92).

Leta 1893 je Matisse postal gostujoči učenec na École des Beaux-Arts v ateljeju simbolističnega slikarja Gustava Moreauja. V njegovem ateljeju se je učil risanja aktov, kar dokumentira slika Atelje Gustava Moreauja (1894/95, zasebna zbirka). Na podestu sredi ateljeja stoji gol ženski model v akademski drži, opirajoč se na palico. Model je s hrbtom obrnjen proti študentom in tudi obraz prekriva senca, kar pomeni, da je bila za slikarje bolj pomembna drža kot identiteta modela. Njena vzravnana drža je v nasprotju s sklonjeno glavo antične skulpture v ozadju. Podoba nam torej sporoča, da so študenti izgubili zanimanje za nekoč občudovano antiko in da jih je pri učenju usmerjala le resničnost. Leta 1895 so Matissa sprejeli na École des Beaux-Arts in tako je tudi uradno postal Moreaujev učenec (Bauer, 1999, 244-245). Moreau je učence pogosto peljal v Louvre, kjer so kopirali stare mojstre, pri tem pa jih je opozarjal na skrivnosti barv in oblik na njihovih delih. Največja Moreaujeva zasluga je bila, da je učencem poskušal vcepiti zavedanje o pomembnosti barve kot nosilke slikarjevega osebnega izraza (Trapp, 1962-1963, 94).

Na vzdolžni format platna je Matisse naslikal Interier s cilindrom (1896, zasebna zbirka). Tak format je najbolj primeren za poglobljen pogled $\mathrm{v}$ prostor, toda Matisse je upodobil le kot interierja $\mathrm{z}$ mizo in predmete okrog nje. Gledalčev pogled najprej pritegnejo številne knjige, mape, papirji, cilinder, vaza in svetilka. Stene so zapolnjene z okvirjenimi slikami, s praznimi okvirji za slike in s kosom nenapetega platna. Še več slik je s sprednjo stranjo prislonjenih $\mathrm{k}$ steni v desnem spodnjem kotu. Čeprav nikjer ne opazimo barv, čopičev, palet ali drugih slikarskih pripomočkov, gre nedvomno za kot ateljeja v petem nadstropju hiše na Quai Saint Michel 19, kamor se je Matisse vselil leta 1894 (Schnell, 2001, 27). Predmetov, kot so nenapeta platna, okvirji za napenjanje platna in prazni okvirji za slike, ne 
srečujemo v zbirkah zbirateljev, temveč v slikarjevem ateljeju. Trditev, da gre za Matissov atelje, dodatno potrjujeta podoba morske krajine v levem zgornjem kotu, ki spominja na krajine, nastale med slikarjevim bivanjem v Bretanji poleti 1895, ter portret nad mizo, kjer naj bi šlo za najstarejši, a žal neohranjeni Matissov avtoportret (Schnell, 2001, 28).

Akt $v$ ateljeju (1898, Tokio, Bridgestone Museum) velja za enega izmed Matissovih zgodnejših velikih ženskih aktov. Kompozicija in pointilistična tehnika spominjata na Seuratove Modele $v$ ateljeju (1888, Merion, The Barnes Foundation), vendar kolorit in poteze čopiča kažejo bolj spontan pristop k slikanju. Na sliki prevladujejo oražnordeči toni, ki jih je umetnik odkril v Bretanji, kjer se je njegova paleta prvič posvetlila. Tako je Matisse svoja pleneristična odkritja prenesel $\mathrm{v}$ ateljejski interier, pri čemer obstaja velika verjetnost, da je upodobitev nastala v Moreaujevem ateljeju, saj je za modelom mogoče opaziti silhuete študentov, ki rišejo (Jacobus, 1980, 90). $\mathrm{V}$ tem času se je namreč še vedno intenzivno posvečal študiju - École des Beaux-Arts je zapustil šele leta 1898. Začel se je ukvarjati s kiparstvom in ta izkušnja je pustila sledove tudi v njegovih slikah. Smisel za modeliranje je pokazal pri Moškem modelu ali Sužnju (1900, New York, The Museum of Modern Art), kjer je uporabil goste nanose barv in občutek plastičnosti ustvaril s kontrastom med okrastim telesom in modrozelenimi ateljejskimi stenami. Slika napoveduje koloristične učinke, ki so zaznamovali kasnejše Matissove upodobitve ateljejev (Jacobus, 1980, 94). Jack D. Flam, eden največjih poznavalcev Matissovih del, je njegov zreli slikarski opus razdelil na pet obdobij: fauvistično obdobje (1900-1908), eksperimentalno obdobje (1908-1917), obdobje v Nici (1917-1929), obdobje ponovne poenostavitve (1929-1940) in obdobje omejitve na bistvo (1940-1954) (Flam, 1982, 25).

V ateljeju na Quai Saint Michel 19 je Matisse naslikal Kot ateljeja (1902, London, Tate Gallery) (Schnell, 2001, 29). Na ozkem prostoru so razvrščeni za slikarjevo delo potrebni pripomočki: na levi je slikarsko stojalo, ob desno steno je prislonjeno $\mathrm{s}$ hrbtne strani vidno platno, $\mathrm{v}$ sredini je stojalo za modeliranje, na katerem pa v nasprotju s pričakovanji ne stoji skulptura, temveč tihožitje. Slednje je edini svetel barvni poudarek med prevladujočimi rjavimi toni. Na vrhu omare v ozadju stojijo skulpture, ki segajo do stropa. Iz kompozicije je mogoče razbrati, da se je avtor hotel predstaviti kot slikar in kipar. 
Atelje na podstrešju (pomlad 1903, Cambridge, The Fitzwilliam Museum) priča o skromnih pogojih, v kakršnih je Matisse ustvarjal na rue Fagard $24 \mathrm{v}$ Bohainu. Podstrešna sobica, ki je slikarju služila kot provizorični atelje, je skoraj prazna. Med opremo opazimo le zložljivo slikarsko stojalo z majhnim platnom, vazo s cvetjem na zložljivi mizi in paleto s čopiči na lesenem zaboju. Predmeti so potisnjeni v drugi plan, medtem ko je v ospredju široka talna ploskev, velik del slike pa zavzema strop. Tako s pomočjo linearne perspektive skonstruirana podoba pritegne gledalčev pogled v notranjost slike in ga vodi do okna v ozadju, skozi katerega se odpira pogled na s soncem obžarjeno pokrajino. Ta je barviti center slike, ki ga kot temen paspartu obkroža ateljejski prostor. Rdečerjavo niansirane stene in ostre sence ustvarjajo iluzijo poglabljanja prostora.

Jeseni 1903 se je Matisse z dvema deloma predstavil na nanovo ustanovljenem Jesenskem salonu (Salon d'Automne). ${ }^{2}$ Spomladi 1904 je razstavljal na Salonu neodvisnih (Salon d'Indépendants), ${ }^{3}$ junija istega leta pa je Ambroise Vollard v svoji galeriji organiziral prvo Matissovo samostojno razstavo. Leta 1905 je na Salonu neodvisnih pritegnil pozornost s sliko Razkošje, mir in slast (1904, Pariz, Musée National d'Art Moderne, Centre Georges Pompidou) ${ }^{4}$ in na Jesenskem salonu šokiral občinstvo skupaj s skupino slikarjev, ki jih je kritik Louis Vauxcelles poimenoval »divje zveri« (les fauves). ${ }^{5}$ Če so Matissova dela dotlej slogovno ustrezala tradiciji 19. stoletja, kažejo slike, nastale poleti

2 Jesenski salon je nastal kot reakcija na konzervativno politiko uradnega Salona v Parizu. Poleg Matissa so bili med ustanovnimi člani Pierre Bonnard, Georges Roualt in Albert Marquet. Na prvem Jesenskem salonu so organizirali spominsko razstavo Gauginovih del, na njej pa so se predstavili še Pierre Bonnard, Maurice Denis, Paul Serusier, Felix Valloton in Édouard Vuillard. Pomembni spominski razstavi sta bili še leta 1905, posvečena Manetu, in 1907 Cézannu, katerih dela so tako postala znana širšemu občinstvu.

3 Salon neodvisnih so poleti 1884 v Parizu ustanovili Albert Dubois-Pillet, Odilon Redon, Georges Seurat in Paul Signac pod geslom Brez žirije in brez nagrad (Sans jury ni récompense). Na njem so lahko razstavljali vsi, ki so plačali pristopnino za razstavo, tako akademski kot amaterski slikarji.

4 Slika kaže vplive neoimpresionistov in je nastala v St. Tropezu, v bližini doma Paula Signaca, čigar knjigo Od Delacroixa do neoimpresionizma je Matisse prebral že leta 1898 ali 1899 in se tako seznanil z divizonistično slikarsko tehniko. Zanimivo je tudi, da je sliko kupil sam Signac.

5 Skupino so sestavljali André Derain, Albert Marquet, Maurice de Vlaminck, Henri Manguin, Raoul Dufy in Georges Rouault. Svoj likovni jezik, za katerega so bile značilne ploskovito poenostavljene oblike in močne barve, so razvili pod vplivom Van Goghovega in Gauginovega postimpresionizma ter Seuratovega pointilizma. 
1905 v sredozemskem pristaniškem mestu Collioure, nove likovne smernice, s katerimi je slikar vplival na razvoj umetnosti v naslednjih desetletjih. Občutja, ki jih je narava izzvala v njem, je izrazil s kričečimi barvami, s čimer je ovrgel do takrat veljavna estetska pravila, oziroma, kot je pojasnil sam: »Fauve pomeni oblikovati s pomočjo barve« (Elderfield, 1992, 133).

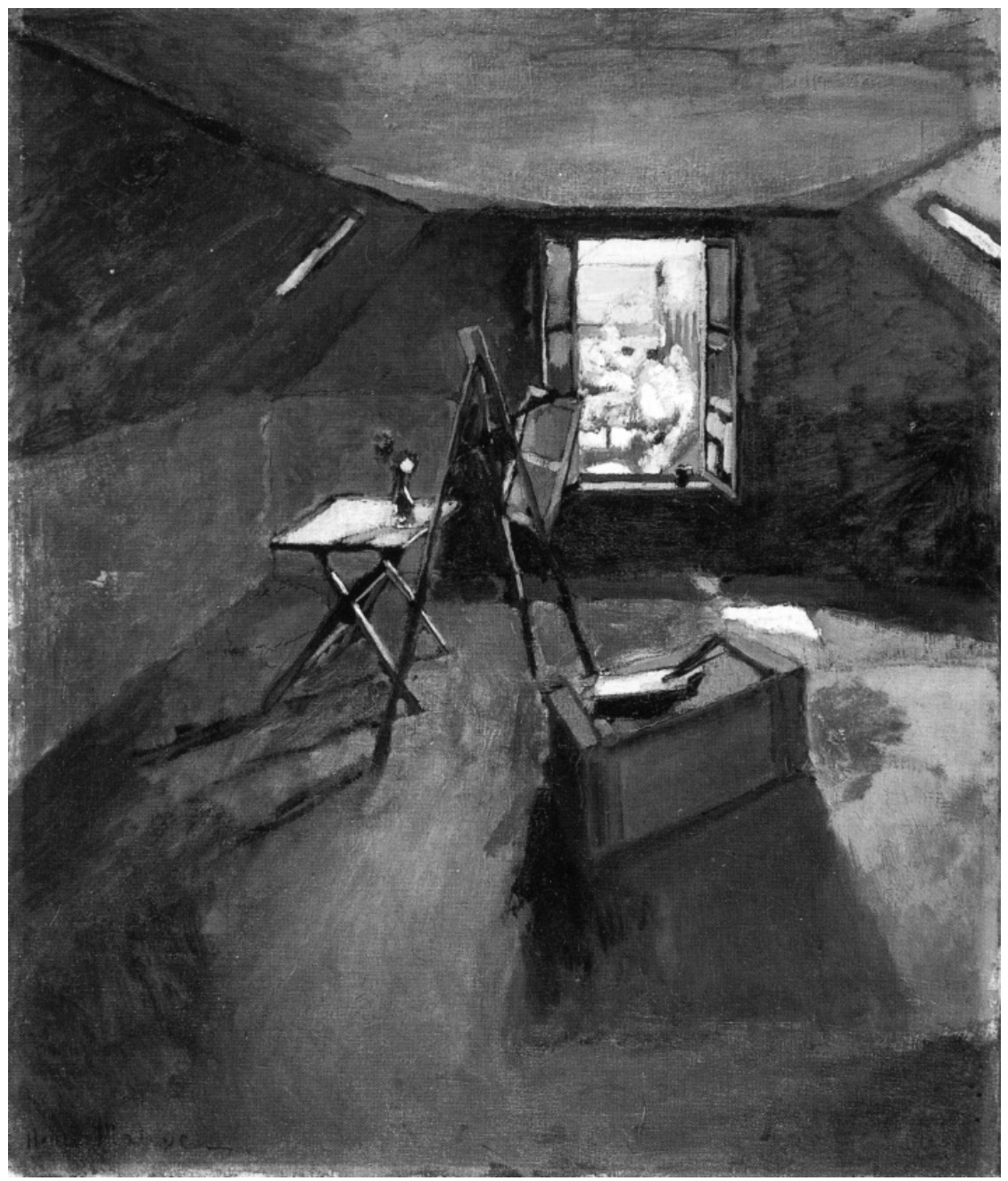

slika 1: Henri Matisse, Atelje na podstrešju, pomlad 1903, The Fitzwilliam Museum, Cambridge Vir: http://www.fitzmuseum.cam.ac.uk/pharos/collection_pages/20th_pages/PD.141964/FRM_PIC_SE-PD.14-1964.html 
Nekaj let Matisse ni upodabljal svojega delovnega prostora in se je k motivu ateljeja ponovno vrnil leta 1909, ko je kupil hišo z velikim vrtom v kraju Issy-les-Moulineaux. Atelje je dal postaviti na severovzhodnem delu zemljišča. Kot pričajo sočasne fotografije, je šlo za leseno montažno stavbo, ki je imela veliko okno na severovzhodni strani ter manjše okno na nasprotni strani in na šedasti strehi. ${ }^{6}$ Novi atelje je v Matissu prebudil ustvarjalni navdih, katerega plod je Rožnati atelje (1911, Moskva, Puškinov muzej) in je bil dotlej največja slika s podobo ateljeja v avtorjevem opusu. Skoraj polovico platna prekriva velika talna ploskev intenzivne rožnate barve, medtem ko je zadnja stena nekoliko svetlejšega odtenka. Prostor napolnjujejo skulpture, slike, risba akta, pohištvo in vaze ter tvorijo raznolik skupek barv in oblik. Ti predmeti in na steni viseča paleta obkrožajo turkizno zelen paravan $s$ cvetličnim vzorcem, ki je glavni poudarek na sliki. Srednje krilo paravana je prekrito s tkanino kraljevsko modre barve, katere rumeni cvetlični vzorec povzema obliko vrčka na stolu pred paravanom. Modra tkanina zakriva železno peč, ki jo prepoznamo po dolgi dimni cevi, ter okno s pogledom na $\mathrm{v}$ sončni svetlobi in vetru trepetajoče drevesno listje.

Na sliki upodobljena dela je mogoče natančno identificirati: kipec levo na stojalu predstavlja Dekorativno figuro (1909, zasebna zbirka), nad njo visi Škrlatna alpska vijolica (1911, zasebna zbirka), ob njej pa je trifiguralna podoba Luxus II (1907, Kopenhagen, Statens Museum for Kunst), ki sega do gornjega roba slike. Nato gledalčev pogled pritegne risba, postavljena na stojalo za modeliranje. Sledita ji sliki Ženska z zelenimi očmi (1908) in Mornar II (1906-07, New York, The Metropolitan Museum of Art). Desno ob oknu je Rožnati akt (1909), četudi ne moremo povsem izključiti možnosti, da gre za Akt $z$ belim šalom (1909, Kopenhagen, Statens Museum for Kunst) (Schnell, 2001, 32-33).

Pod omenjeno sliko stoji v profilu odlitek Marsa Borghese. Obrnjen je proti sliki ženskega akta, ki prikazuje prvo verzijo reliefa Hrbet I (1909).

6 Matissovo hišo in atelje je natančno opisala ameriška slikarka in pisateljica Clara Taggart MacCheseny (1860-1928): »Njegovo dvonadstropno francosko vilo $\mathrm{z}$ vrtom je obdajal zid. Do ateljeja so vodile cvetlične gredice in drevesa. Atelje je imel kvadratno zasnovo in velika okna na stenah in na strehi, zato je bilo v njem vroče. Zunanje in notranje stene so imele bel oplesk. Ateljejske stene in slikarska stojala pa so zapolnjevala velike slike žarečih barv.» (MacCheseny, 1982, 95-96) 
Matisse je namreč svoja kiparska dela pogosto postavljal v jukstapozicijo z odlitki antičnih skulptur in se tako meril s slavnimi historičnimi vzori, dasi je s svojimi plastikami sledil popolnoma drugačnim ciljem. Skrajno desno, za zelenim vrčem, je mogoče prepoznati levi rob slike Ples (1909, New York, The Museum of Modern Art), kjer pa gre verjetno za študijo, saj delo leta 1911 ni bilo več v Matissovem ateljeju (Schnell, 2001, 34).

Umetnik je svoja dela pregledno razporedil po ateljeju in se predstavil kot mojster risbe, slikarstva in kiparstva, čeprav je zakril vse sledove svojega ustvarjanja. Od slikarskega pribora je naslikal le paleto, ki neopazno visi na steni, in jo omejil na rjavo ploskev, da se ujema $\mathrm{z}$ drugim pohištvom. Med slikami je najbolj izpostavljena Ženska z zelenimi očmi, kar lahko interpretiramo kot samozavesten odziv na negativne kritike, ki jih je jeseni leta 1910 prejela v Londonu (Schnell, 2001, 34). Bolj kot umetnine pritegneta pogled preproga in paravan. S črnimi črtami izražene gube na tkanini potekajo vzporedno s slikovno ploskvijo in prekinjajo cvetlični vzorec, vendar ustvarjajo občutek volumna. Matissova odločitev, da ne bo upodobil delovnih pogojev v ateljeju in ustvarjalnega procesa, $\mathrm{v}$ katerega je vložil veliko časa in truda, vodi k prepričanju, da slikar ni hotel poudariti razlike med bivalnim in delovnim prostorom. V tem smislu lahko Rožnati atelje razumemo tudi kot upodobitev galerijskega prostora, ki gledalce vabi k ogledu.

Jeseni 1911 je Matisse naslikal Rdeči atelje ali Rdečo sliko, kot je bilo delo naslovljeno na prvih razstavah. ${ }^{7}$ Oba naslova se zdita enako primerna, saj nas najprej prevzame velika, enakomerno pobarvana rdečerjava osnovna ploskev, ${ }^{8}$ šele trenutek za tem opazimo opremo ateljejskega interierja. Predstavo prostora je slikar ponazoril z linearno perspektivo, pri čemer se ni

7 Na razstavi postimpresionistov v Grafton Galleries v Londonu 5.10.-31.12.1912 in leto kasneje na Armory Showu v New Yorku, v Chicagu in Bostonu.

Že leta 1877 je Louis Anquetin na sliki Čoln v večerni zarji, ki se ni ohranila in jo poznamo samo po opisih kritikov, uporabil velike rdeče ploskve, pri čemer se je zgledoval po japonskih lesorezih. Anquetinova slika je Paula Gaugina verjetno spodbudila, da je poleti 1888 naslikal Vizijo po pridigi ali Jakobov boj $z$ angelom in $\mathrm{z}$ veliko rdečo ploskvijo ustvaril magičen prostor, kjer se odvija čudežni dogodek. Po mnenju Alberta Kosténévicha pa se je Matisse odločil, da bo naslikal Rdeči atelje šele potem, ko je na svojem kratkem potovanju v Rusijo novembra 1911 v zbirki Morosowa v Moskvi videl Van Goghovo Nočno kavarno, nastalo septembra 1888, in nekaj tednov mlajšo Gauginovo Kavarno (Kosténévich, Sémionova, 1993, 23-36). 
držal tradicionalnih pravil, temveč je izbral svoboden pristop, kajti bežišča, kamor bi se naj stekale vse linije, ni. ${ }^{9}$ Ob tem se zdi, da sliko levo spodaj predira mizna plošča, ki se domnevno zaključuje v gledalčevem prostoru. $\mathrm{Na}$ mizi, pokriti s prtom, so razporejeni različni predmeti. Spodnjega roba platna se dotika na mizi ležeč krožnik, na katerem je na beli osnovi upodobljena modra ženska figura, obdana s cvetličnim vzorcem. Krožnik ni bil namenjen za domačo uporabo, marveč je umetniški izdelek, ki opozarja na še eno priljubljeno Matissovo likovno tehniko. Na levem robu mize stoji pecljat kozarec, na zgornjem robu pa temnozelena trebušasta perzijska vaza. Iz vazinega visokega vitkega vratu se vijeta vitici z okroglimi listi in ovijata okrasti kipec, kjer je umetnik kot predlogo uporabil Akt $z$ vznak nagnjeno glavo (1904/06, zasebna zbirka) (Schnell, 2001, 183). Ob desnem robu mize je posoda s svinčniki, njena kvadrasta oblika povzema obliko mize.

Mizi je ekvivalenten stol v desnem spodnjem kotu. Naslonilo stola sega do polovice višine platna, noge pa se domnevno nadaljujejo $\mathrm{v}$ gledalčev prostor. Vendar stola in na obliko sklede spominjajočega naslanjača za njim ne zaznamuje značilna predmetna trdnost, saj sta izrisana samo s tanko rumeno črto. Za naslanjačem je mizica, o funkciji katere govori krožnik na njej, saj bi v nasprotnem primeru imeli občutek, da lebdi v zraku. Medtem ko je Matisse levi kot platna zapolnil z mizo, desni kot pa s stolom, je center slike pustil prazen; mogoče $\mathrm{z}$ namenom, da bi pritegnil gledalca in ga povabil, da stopi v atelje in si ogleda slike, razporejene na stenah okoli stoječe ure in komode.

Veliko platno na levi steni prikazuje s cvetjem obdan ženski akt in povzema obliko paralelograma, s čimer poskuša ustvariti vtis prostorskega poglabljanja. Gre za izgubljeno sliko z naslovom Veliki akt - Noč (1911), ki jo poznamo samo s fotografij. Desno visi manjša slika, ki jo razpolavlja zgornji rob platna, in prav tako prikazuje ženski akt v podobni drži. V tem primeru sta možni dve razlagi: da je pred nami Akt z belim šalom (1909) ali Rožnati akt, ki smo ga srečali pri Rožnatem ateljeju. Na tleh pod malim aktom je k steni prislonjen prazen okvir in več manjših slik, a samo vrhnja razkriva prizor krajine, kjer gre za upodobitev Dvorišča mlina v Ajacciu

9 Matisssa je k opuščanju perspektive pri oblikovanju interierjev spodbudila razstava perzijskih miniatur, ki si jo je sredi oktobra 1910 ogledal v Münchnu (Elderfield, 1992, 183). 
(1898, Köln, Wallraf-Richartz-Museum). Zraven stoji visok in ozek kos pohištva, pri katerem okrogla številčnica, čeprav nima kazalcev, kaže, da gre za stoječo uro. Tik ob njej je komoda s tremi predali, ki jo delno prekriva slika Nimfa in Favn (1909, izgubljena). Ker je komoda upodobljena frontalno, pri čemer njeno horizontalno linijo stopnjuje na steni naslikan rjav trak z rumenim arabesknim vzorcem, nam pri dojemanju prostornine pomagajo na vrhu komode razporejene posode. Nad komodo visijo že z Rožnatega ateljeja znana dela Mornar in Škrlatna alpska vijolica ter Luxus II. Pravokotne oblike pohištva in slik je Matisse uravnotežil z okroglo, verjetno iz terakote narejeno talno vazo. Četudi vaza ni strogo simetrična, kot so resnične glinene posode, iz njene oblike izhaja organska vitalnost, ki se ujema $\mathrm{z}$ akti na slikah in $\mathrm{s}$ kipcema na modelirnih stojalih $\mathrm{v}$ desnem zadnjem kotu. Prva skulptura v barvi umbre predstavlja Dekorativno figuro, v obrisih bele skulpture pa je mogoče prepoznati Jeannette IV (1911, New York, The Museum of Modern Art) (Schnell, 2001, 68-70).

Predmeti na mizi so kot pohištvo in umetnine $\mathrm{v}$ ateljeju razporejeni okoli prazne površine na sredini. Medtem ko so slikarji v preteklosti s pomočjo perspektivičnega nizanja talnih oblog ter s svetlenjem in senčenjem ustvarili iluzijo prostora, je Matisse tla zaznamoval $\mathrm{z}$ enotno barvno ploskvijo. Enako je storil pri stenah, slikah in pohištvu, zato se kljub njihovi linijski konstrukciji zdi, da se stapljajo z osnovno ploskvijo. Poleg tega ni nakazal kotov in stropa ateljeja, s čimer bi omilil ploskoviti vtis slike, in tudi linija na levi, ki se izteka $\mathrm{v}$ spodnji rob velikega akta, ne pripomore $\mathrm{k}$ nazornejši prostorski predstavnosti. Tako lahko samo ugibamo, ali so rdeča tla obložena $\mathrm{z}$ lesom, linolejem ali s kamnom, so rdeče stene ometane, obložene z lesom ali prekrite s tapetami, so mize pogrnjene s prtom, papirjem ali usnjem ter ali so stojala za modeliranje lesena ali kovinska. Matisse namreč ni hotel posnemati stvarnega sveta, ampak z barvo in formo izraziti občutja, ki so jih v določenem trenutku v njem prebudili modeli ali predmeti. Ali, kot je rekel MacChesenyjevi: »Ne slikam mize, marveč vtis, ki ga ta naredi name.« (MacCheseny, 1982, 97) ${ }^{10}$

10 Kako dolgotrajen in težaven je bil pri nastajanju Rdečega ateljeja proces iskanja občutjem ustrezne barve, je razvidno iz pogovora med Matissom ter danskim slikarjem in kritikom Ernstom Goldschmidtom (1879-1959), ki je pozno jeseni 1911 obiskal slikarja v Issy-lesMoulineauxu: »Ko sem si ogledoval na sliki upodobljene predmete in jih primerjal s tistim, 
Izbira rdeče barve je gotovo povezana s slikarjevo željo, da bi spojil podobo z osnovno ploskvijo in dosegel edinstven likovni učinek, kajti nikjer v naravi ne srečamo tako velikih enakomerno rdečih barvnih ploskev, pa tudi stene interierjev so redko pobarvane $\mathrm{z}$ rdečo barvo, vendar niso nikoli $\mathrm{v}$ tako intenzivnem odtenku. Interierja, kjer bi bila poleg sten rdeča tudi tla in inventar, ni mogoče najti nikjer, saj v takšnem prostoru ne bi bilo mogoče zdržati dlje časa. Izumetničenost oziroma nenaravnost situacije ne bi mogla biti bolj poudarjena, kot je na Rdečem ateljeju, zato njegova intenzivna rdeča barva ne more biti odraz konkretne svetlobne situacije ali paslika, ki naj bi se po mnenju nekaterih umetnostnih zgodovinarjev izoblikovala v slikarjevih očeh, ko je prišel z vrta v atelje. ${ }^{11}$ Očitno je bila rdeča barva tista, ki je najbolje izrazila občutja, ki jih je v določenem trenutku leta 1911 v Matissu vzbudil njegov atelje, in čeprav Goldschmidtu ni znal pojasniti, zakaj je uporabil prav to barvo, se je nedvomno zavedal njene moči. Rdeča je namreč v primerjavi z drugimi barvami najbolj opazna in človeka najbolj čustveno prevzame, saj spominja na kri in ogenj, simbolizira ljubezen in revolucijo ter izraža dostojanstvo kraljev, kardinalov in mučenikov (Fourcade, 1972, 246-248).

Pogosto samo redka znamenja na slikah aludirajo na Matissov atelje v Issy-les-Moulineauxu ali v Parizu na Quai Saint Michel. Na sliki Kot ateljeja (1912, Moskva, Puškinov muzej) se spet pojavlja svetlomodri paravan, čez katerega visi temnomodra tkanina s cvetličnim vzorcem in spominja na Rožnati atelje. Pred paravanom na svetlozelenih tleh stoji temnozelena arabska vaza, katere vrh krona kapucinka v oranžnordečem lončku. V levem spodnjem kotu je ležalni stol s platnom z rdečimi in rumenimi progami, ki ga razpolavlja levi rob slike. Ležalni stol je najpomembnejši kom-

kar sem videl v ateljeju, me je Matisse vprašal: »Iščete rdečo steno? Takšna stena ne obstaja. Kot lahko vidite, sem iste predmete naslikal pred modrosivo ateljejsko steno. To so eksperimenti, študije, ki me kot končana dela niso zadovoljila. Ko sem odkril rdečo barvo, sem te študije postavil v kot ateljeja, kjer bodo tudi ostale. Sam ne vem, kje sem dobil idejo za rdečo barvo. Sprehodiva se po vrtu in mogoče se bo med tem to vprašanje razrešilo. Ugotovil sem namreč, da vse stvari - cvetlice, pohištvo in komoda - zame postanejo to, kar so, ko jih vidim skupaj z rdečo barvo, čeprav ne vem, zakaj je temu tako.«(Flam, 1994, 128)

11 Schnellova $(2001,64)$ teza se mi zdi verjetnejša kot Elderfieldova $(1978,88)$, ki je povzel mnenje Louisa Aragona iz romana o Henriju Matissu iz leta 1971, da gre za pasliko. 
pozicijski element in zdi se, da je pravkar nekdo vstal z njega, saj proge na platnu, ki je vpeto v stol, še vijugajo po zraku.

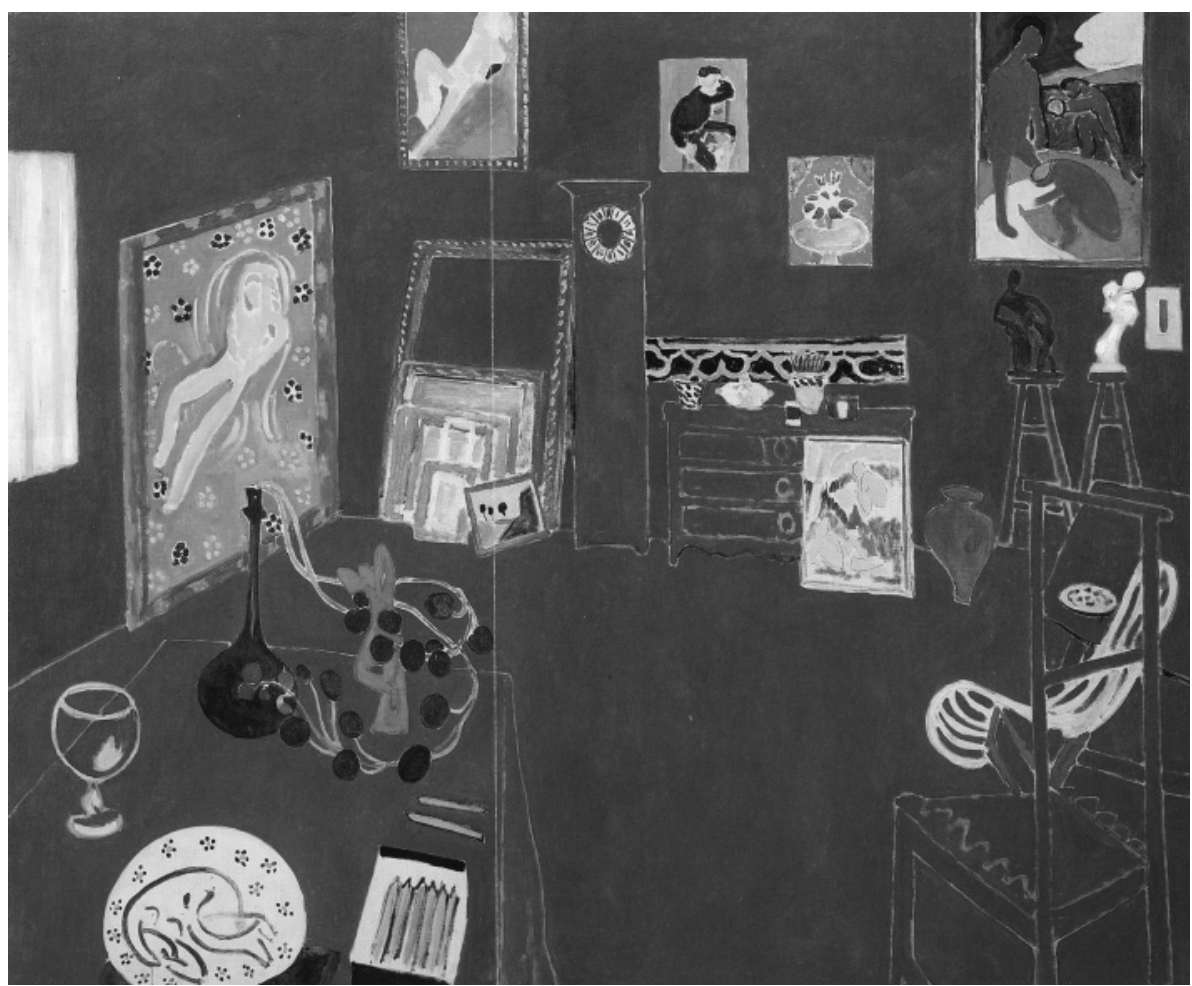

slika 2: Henri Matisse, Rdeči Atelje, 1911, New York, The Museum of Modern Art Vir: http://www.moma.org/collection/browse_results.php?criteria=O\%3AAD\%3AE \%3A3832\&page_number=47\&template_id=1\&sort_order $=1$

Na Interierju z zlato ribico (1914, Pariz, Musée National d'Art Moderne, Centre Georges Pompidou) Matissov pariški atelje zaznamuje pogled skozi okno na prefekturo na Quai Saint Michel. Še bolj domiselno je isti prostor skonstruiran na sliki Zlata ribica in paleta (1914, New York, The Museum of Modern Art), kjer je miza, na kateri je posoda z zlato ribico in rožami, postavljena pred okensko ograjo. Mizo hkrati zastira velik črn pravokotnik, ki se je kot gledališka kulisa vrinil v prostor, segajoč od zgornjega do spodnjega roba platna. Ob desni strani pravokotnika opazimo belo pravokotno paleto, skozi katero moli palec, ki najverjetneje pripada slikarju, čeprav 
njegova figura ni vidna. Tako je Matisse gledalca postavil pred slikovno uganko in mu ni razkril procesa nastajanja slike, s čimer bi opozoril na trud, ki ga je treba vložiti, da nastane umetniško delo, kar dokazujejo številne preslikave in vpraskane linije na platnu.

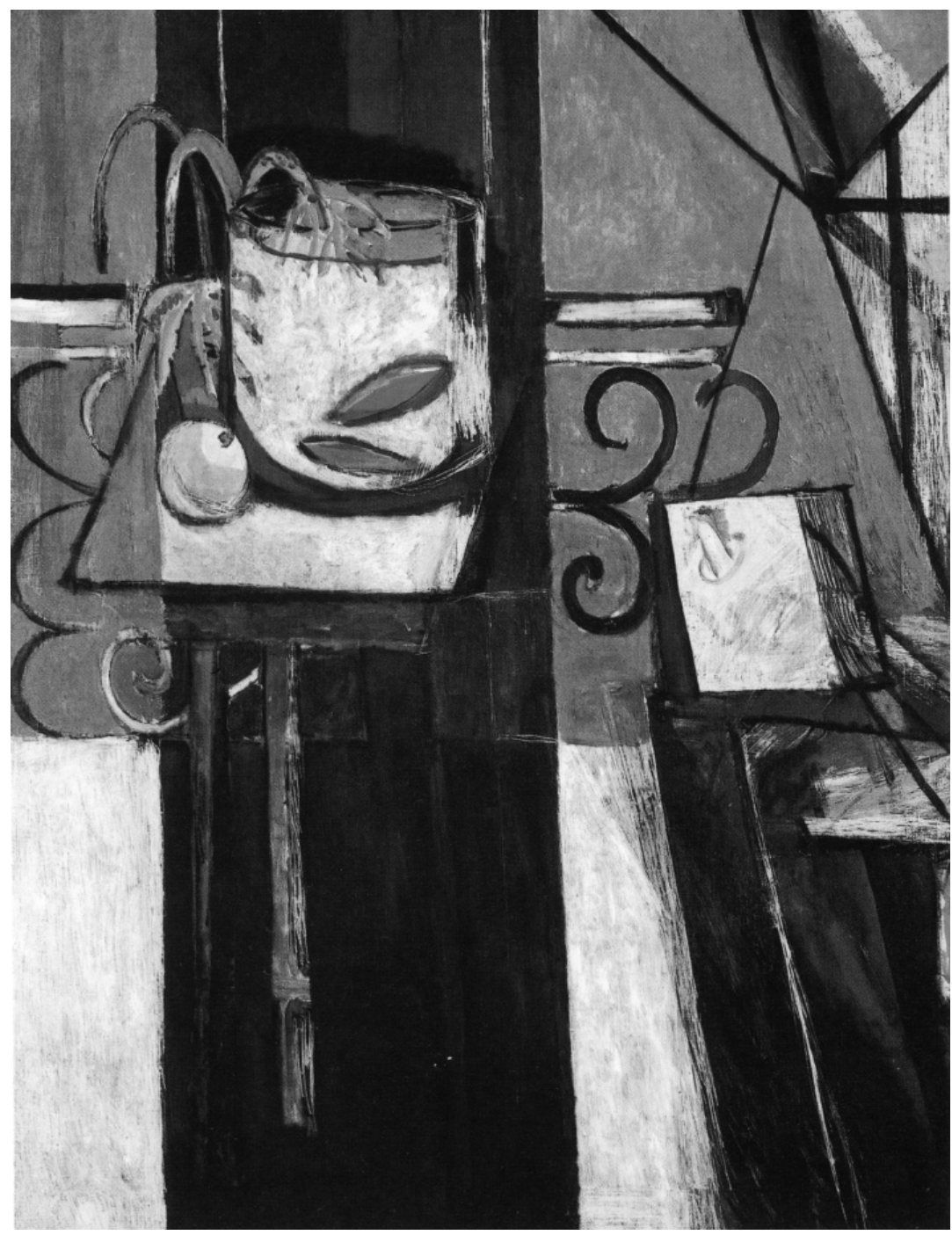

slika 3: Henri Matisse, Zlata ribica in paleta, 1914, The Museum of Modern Art, New York

Vir: http://www.moma.org/collection/browse_results.php?criteria=O\%3AAD\%3AE \%3A3832\&page_number=80\&template_id=1\&sort_order $=1$ 
V Ateljeju na Quai Saint Michel (1916, Washington D.C., The Philips Collection) na postelji v ozadju leži gol model, skozi okno na desni se odpira pogled na mesto, levo v ospredju pa sta dva stola. Spet manjka figura slikarja, čigar najprimernejši položaj za opazovanje modela bi bil poleg gledalca. Tokrat je Matisse izjemno domiselno izenačil slikarjev pogled z gledalčevim in ga tako postavil v vlogo voajerja. Šele pri upodobitvi Slikar $v$ ateljeju (jesen 1916, Pariz, Musée National d’Art Moderne, Centre Georges Pompidou) naletimo na klasično trojico, sestavljeno iz slikarja, modela in nastajajočega dela. Model in njegova podoba na platnu se ujemata tako po koloritu kot po ploskovito izraženem telesu. Tudi figura slikarja ustreza barvi njegove palete, s katero tvorita ploskovni monolit. Za stene je slikar uporabil enotno belo in črno ploskev ter tako prostor približal osnovni ploskvi.

Od leta 1916 je Matisse zaradi kroničnega bronhitisa zime preživljal v Nici. Največkrat je bival v hotelih in hotelsko sobo spremenil v občasni atelje. V enem od njih je nastala Ura slikanja (1919, Edinburgh, National Galleries of Scotland). Prostor na sliki je komaj nakazan in ga omejuje črno monokromno ozadje, spominjajoče na svileno tkanino. $\mathrm{V}$ središču je miza, ki jo povsem zakriva bel prt. Miza deluje kot kamniti blok in le gube na prtu ustvarjajo vtis globine. Na mizi ležijo čopič, dve limoni in vaza s šopkom. Skrajno desno pri mizi sedi deklica, sklonjena nad knjigo - gre za osemnajstletni model Antoinette Arnoux. ${ }^{12} \mathrm{~V}$ levem kotu sedi slikar pred slikarskim stojalom s platnom in portretira deklico. Slikarjeva figura je podana ploskovito in je vidna samo $s$ hrbtne strani. Temino ozadja predira ovalno ogledalo $\mathrm{v}$ medeninastem okvirju, čeprav ni jasno, ali stoji na robu mize ali visi na steni. V ogledalu se zrcalita vaza s šopkom in morska krajina s palmami. Tako je Matisse ploskovito zasnovano sliko razširil s podobo v ogledalu, ki nam pripoveduje, da se v ozadju odpira prostrano Sredozemsko morje.

Na sliki Akt vateljeju (1928, zasebna zbirka) je Matisse ponovno izpustil figuro slikarja in njegovo namišljeno pozicijo izenačil z gledalčevo. $\mathrm{Na}$ to namiguje paleta, ki leži na podstavku na spodnjem robu slike in je pri roki slikarju, ki se domnevno nahaja v istem prostoru kot gledalec. Domnevo potrjuje podoba $\mathrm{v}$ zrcalu, stoječem poleg modela, in prikazuje slikarja pri

12 http://www.nationalgalleries.org/index.php/collection/online_az/4:322/results/0/694/ $<27.8 .2009>$. 
delu. Matisse se je ponovno izkazal za mojstra likovnih zvijač, saj mu je uspelo gledalca pretentati in mu vzbuditi iluzijo, da se je naključno znašel v njegovem ateljeju in je priča nastajanju nove umetnine.

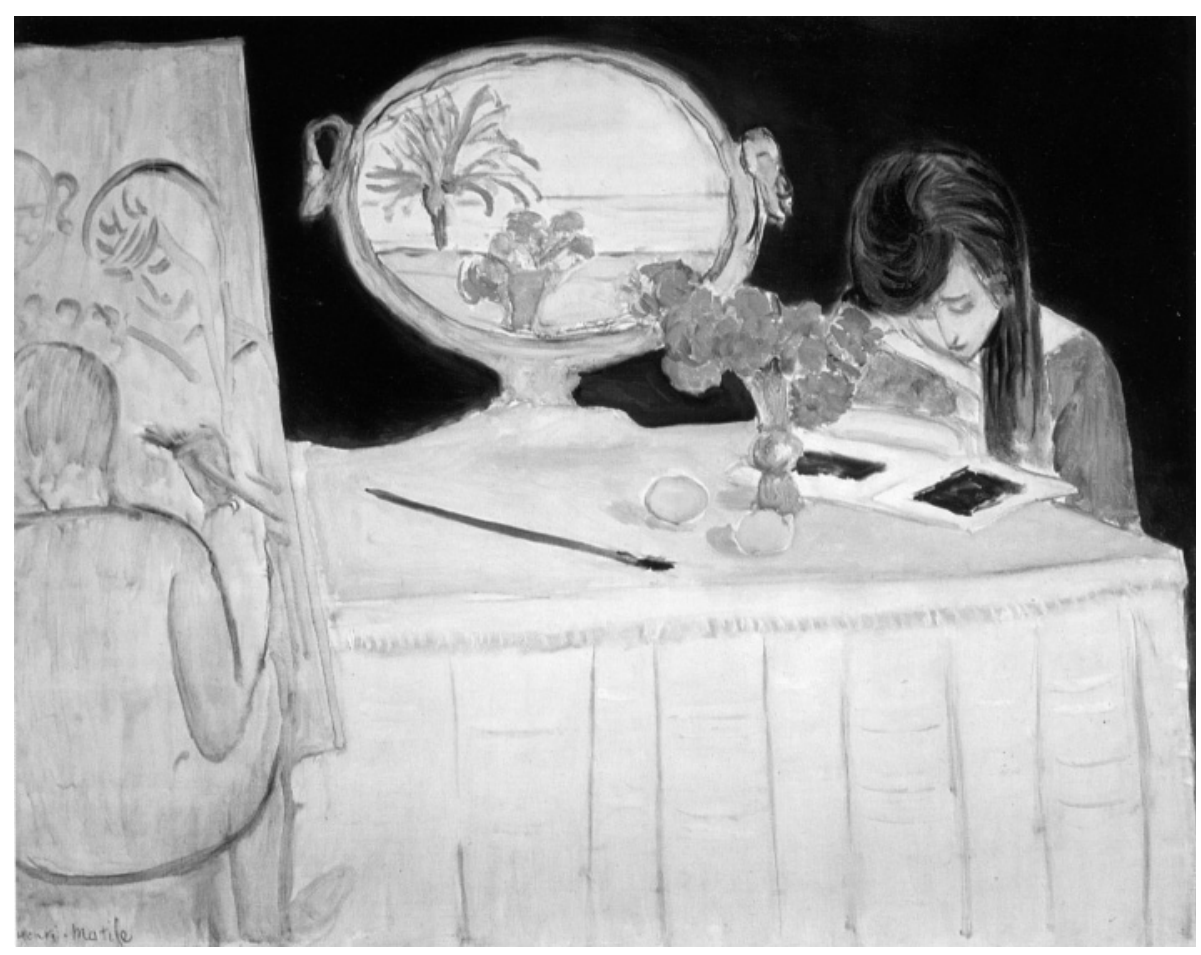

slika 4: Henri Matisse, Ura slikanja, 1919, National Galleries of Scotland, Edinburgh

Vir: http://www.nationalgalleries.org/index.php/collection/online_az/4:322/ results/0/694/

Atelje v Nici (1929, Berlin, Museum Berggruen) ožarja sredozemska svetloba. Tla, ki jih prekriva intenzivna rdeča barva, so reminiscenca $R d e$ čega ateljeja, na levi steni visi sončevo rumena zavesa, naravnost pa se odpira pogled skozi okno v modrozeleno sredozemsko pokrajino. V ateljeju opazimo slikarsko stojalo s platnom, stojalo za modeliranje, mize, stole, lončnico in še nekaj drobnega inventarja. Četudi pogrešamo figuro slikarja ali modela, tega ne občutimo kot pomanjkanje, saj nas ateljejski interier kot glavni protagonist v soigri s soncem obžarjeno pokrajino povsem prepriča. 
Naslednjih dvajset let Matisse ni upodabljal ateljejev a je malo pred svojim osemdesetim rojstnim dnem naslikal Veliki rdeči interier (1948, Pariz, Musée National d’Art Moderne, Centre Georges Pompidou), kjer je še enkrat parafraziral Rdeči atelje. Tokrat je izbral pokončni format platna in ga enakomerno prekril z rdečo podslikavo, ki jo je pustil vidno, ter z minimalnimi tonskimi razlikami ustvaril občutek prostorske globine in utripanje površine. Hkrati je opustil linijske označbe meja med stenami in tlemi ter tako prispeval k večji ploskovni enotnosti. Izrazno moč rdeče barve je stopnjeval z živorumenimi živalskimi kožami na tleh in s cvetličnimi tihožitji na mizah. Vrhunec izraznosti pa rdeča barva doseže na risbi in sliki, ki visita na steni in se spajata $z$ osnovno ploskvijo. Tako je Matisse še zadnjič dokazal svoje mojstrstvo v likovnem snovanju ateljejskih interierjev, s katerimi je revolucioniral umetnost prve polovice 20. stoletja in vplival na slikarje v drugi polovici stoletja.

Največ občudovanja je med Matissovimi ateljeji požel Rdeči atelje, ki je postal širše znan februarja 1948, ko so ga razstavili v newyorški galeriji Bignou. Slika je navdušila tudi najvplivnejšega ameriškega likovnega kritika in vnetega zagovornika ameriškega abstraktnega ekspresionizma Clementa Greenberga. Po njegovem mnenju je bil Henri Matisse največji tedaj živeči slikar, ki je leta 1911 ustvaril dotlej najbolj ploskovito sliko, zato je bil za mlade slikarje pomembnejši od Picassa (Greenberg, 1986, 194). Vendar je leta 1953 Greenberg napačno zapisal, da osnovne ploskve na Rdečem ateljeju ne prekriva pigment, kajti platno naj bi bilo tako prepojeno (soaked) s pigmentom, da sta se osnovna ploskev in platno poenotila (Greenberg, 1953). Opisana tehnika ne ustreza resničnosti, saj je Matisse $\mathrm{z}$ rdečo barvo prekril modro osnovo in pri tem natančno pazil, da ne bi zakril vseh prvotnih posegov na platnu. Postopek soak-staining je šele 26. oktobra 1952 razvila Greenbergova prijateljica umetnica Helen Frankenthaler na sliki Gore in morje (Washington D.C., National Gallery of Art), kjer je barvo polila na negrundirano platno in ga torej prepojila $\mathrm{z}$ barvo, s čimer jo je izenačila $\mathrm{z}$ osnovno ploskvijo. O napačnosti Greenbergove trditve, ki je tehniko staininga pripisoval Matissu, se je lahko vsak prepričal že leta 1949, saj od takrat v Muzeju moderne umetnosti v New Yorku še danes visi Rdeči atelje. 


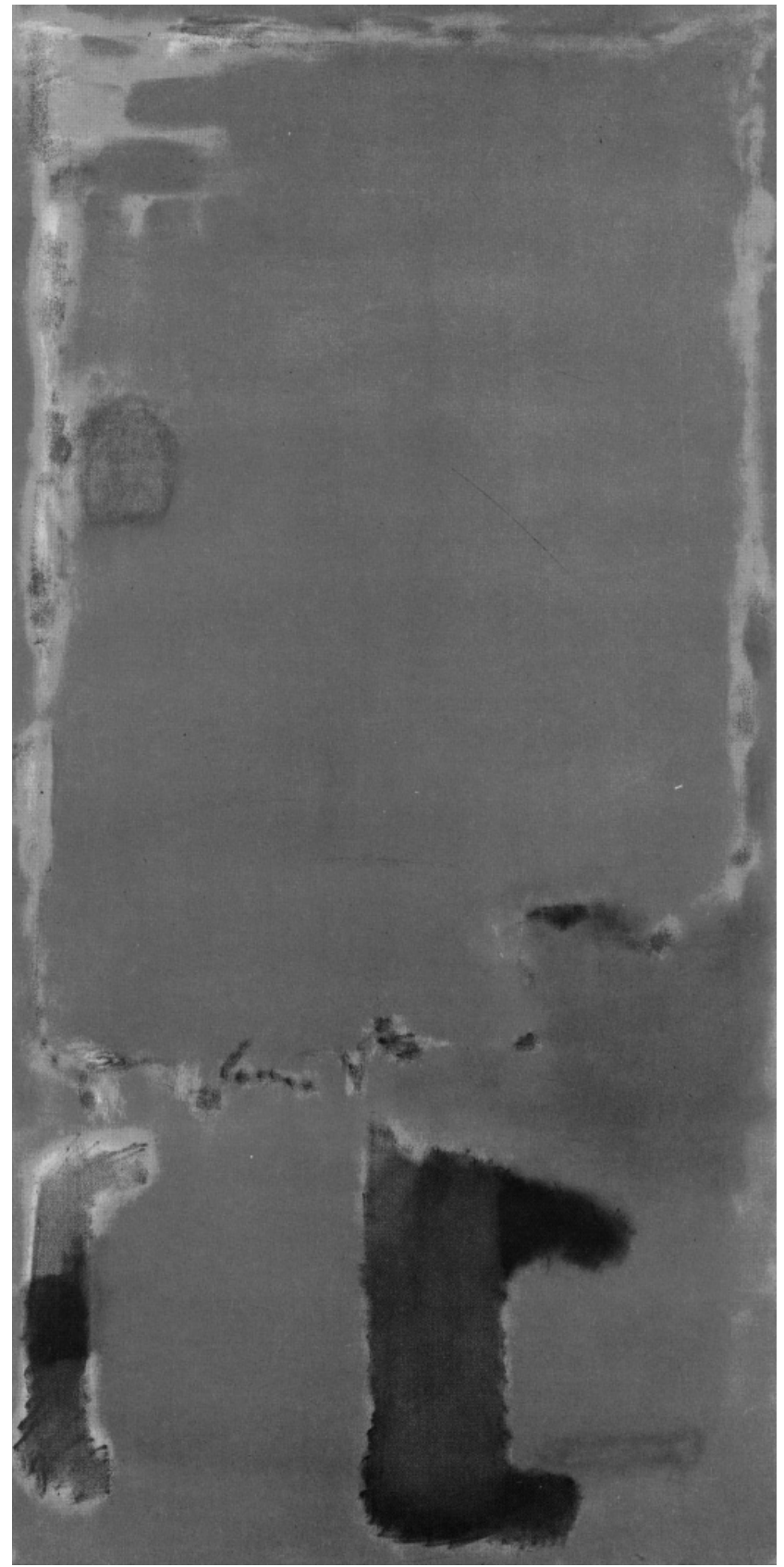

slika 5: Mark Rothko, Number 21/ Brez naslova, 1949, The Metropolitan Museum of Art, New York Vir: Schnell (2001) 
Mark Rothko (1903-1970) je v newyorškem Muzeju moderne umetnosti pred Rdečim ateljejem prebil ure in ure. Tukaj je doživel svoje Savlovo spreobrnjenje oziroma, kot se je kasneje spominjal, se je med neprenehnim opazovanjem Rdečega ateljeja rodila njegova umetnost (Ashton, 1983, 187). Rothka je prevzela intenziteta rdeče barve, ki jo je Matisse dosegel z enakomernim barvnim nanosom in velikim formatom platna. Slednje je Rothko dosledno upošteval pri sliki Number 21/Brez naslova (1949, New York, The Metropolitan Museum of Art). Veliko pokončno platno je prekril z rdečo barvo, katere monokromnost prekinjajo oranžni robovi z redkimi zelenimi poudarki in temnomodri madeži. Toda barvnih nanosov na Rothkovih delih ni mogoče natančno razmejiti, saj se zdijo kot druga na drugo položene barvne koprene ali dimne zavese. Takšno gradnjo slik je Rothko po letu 1950 neprestano izpopolnjeval in variiral ter se vedno bolj oddaljeval od svojega vzornika.

Še bolj se je leta 1948 Rdečemu ateljeju približal Barnett Newman (1905-1970) s sliko Ornament I (New York, The Museum of Modern Art), ki jo prekriva enakomerna plast rdečerjave barve, na sredini pa jo razpolavlja oranžna linija. Vendar če verjamemo umetnikovi trditvi, da je delo nastalo 29.1.1948, na njegov triinštirideseti rojstni dan, ugotovimo, da se ni mogel zgledovati po Rdečem ateljeju, saj so ga v newyorški galeriji Bignou razstavili šele februarja istega leta. Čeprav Newman v nasprotju z Rothkom nikoli ni omenjal vpliva Matissovega dela na svoje slikarstvo, se zdi naključnost nastanka Ornamenta I na umetnikov rojstni dan precej neverjetna in meji na legendo. Četudi bi lahko, glede na dejstvo, da ne gre za neposreden prenos motiva ali povzemanje sloga, ovrgli predvidevanja, da je Newmanova slika nastala po ogledu razstave Matissovih del v galeriji Bignou, pa lahko z gotovostjo sklepamo, da je umetnik doživel potrditev svojega dela, ko je leta 1949 v Muzeju moderne umetnosti v New Yorku videl Rdeči atelje, ne glede na to, ali ga je k temu navedel notranji vzgib ali ga je spodbudil Rothko, s katerim sta prijateljevala vse do spora leta 1952 (Breslin, 1993, 322). 


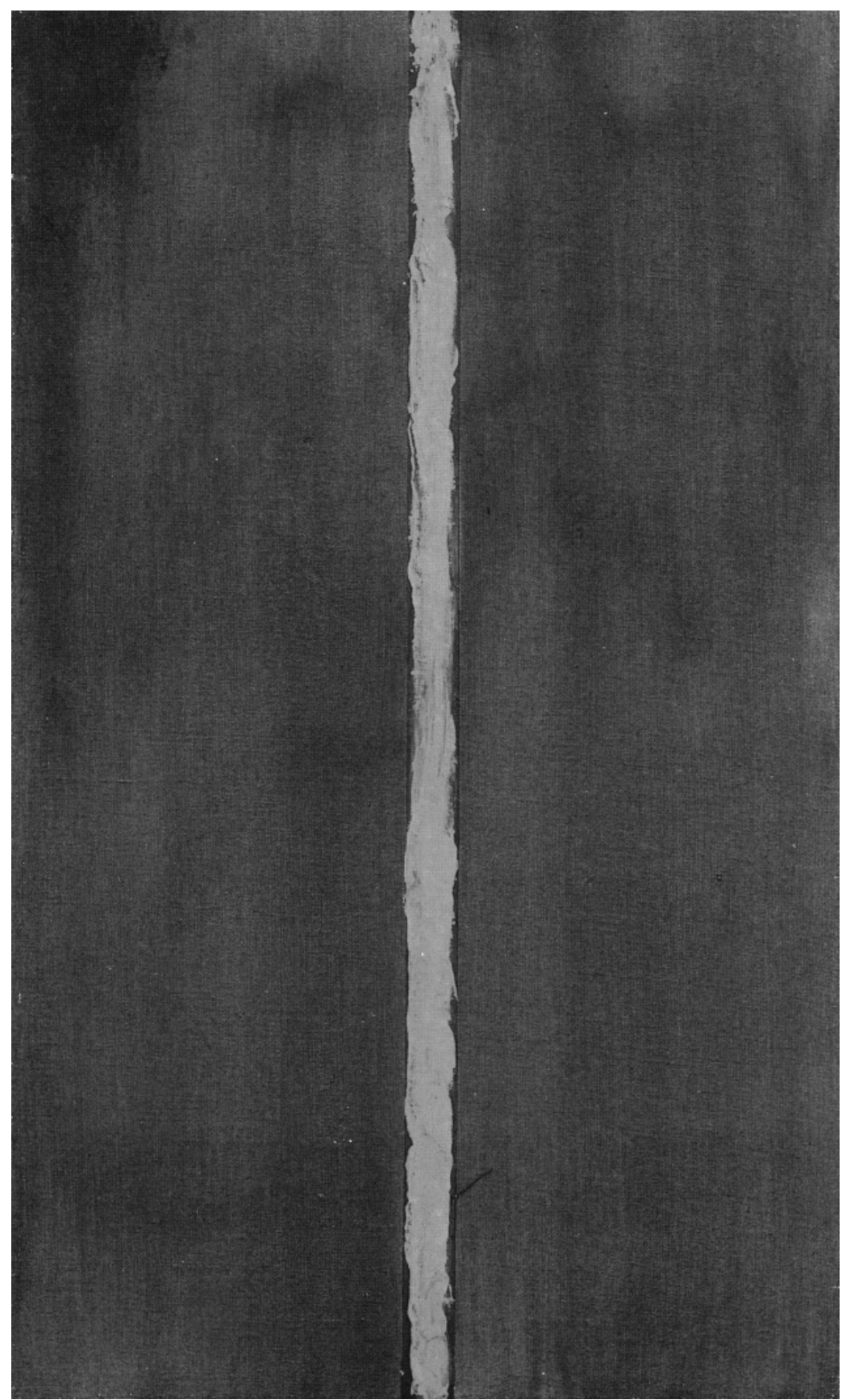

slika 6: Barnett Newman, Ornament I, The Museum of Modern Art, New York Vir: Schnell (2001) 
Robert Motherwell (1915-1991), najmlajši predstavnik newyorške šole, je leta 1977 naslikal skoraj monokromni Rdeči feničanski atelje (Bilbao, Guggenheim Museum) in se tako poklonil Matissovemu Rdečemu ateljeju. Rdečino prekinja $\mathrm{z}$ ogljem izrisan pravokotnik na desnem zgornjem robu platna. Sredi pravokotnika je belo polje kot ostanek nepobarvane podslikave, na katerem sta z ogljem zapisani dve feničanski črki, ki ju je Motherwell občudoval, saj naj bi po njegovem prepričanju iz njih izvirala gestualna izraznost. ${ }^{13} \mathrm{Na}$ ta način je ustvaril fiksacijsko polje, kjer se ustavi gledalčevo oko, potem ko neha tavati po rdeči praznini, s čimer je dosegel podoben učinek kot Matisse s slikami na Rdečem ateljeju.

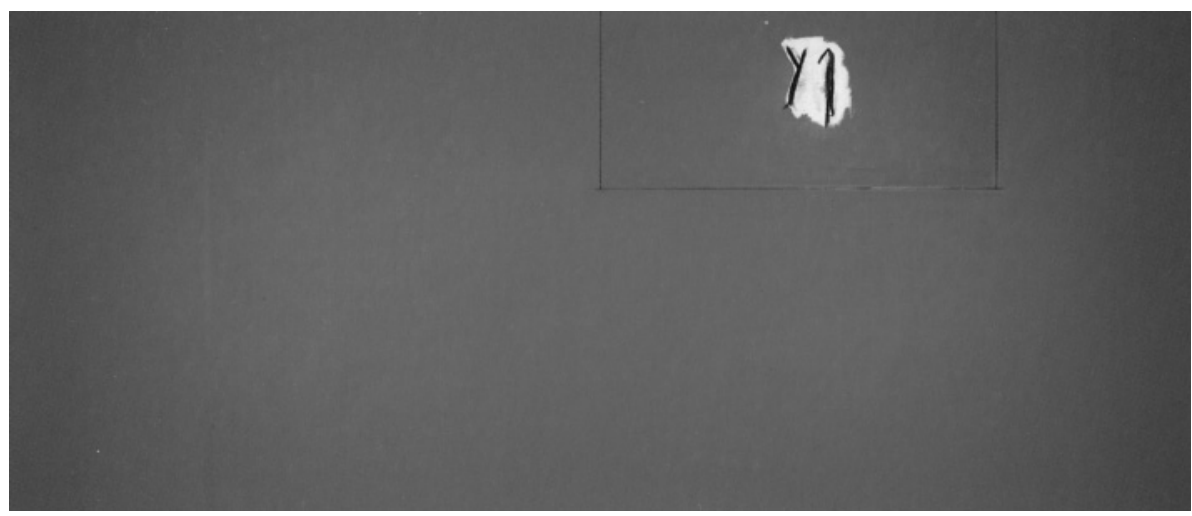

slika 7: Robert Motherwell, Rdeči feničanski atelje, 1977, Guggenheim Museum, Bilbao

Vir: http://www.guggenheim-bilbao.es/secciones/la_coleccion/nombre_obra_ ficha_tecnica.php?idioma $=$ en\&id_obra $=59 \&$ anterior $=$ buscar obra\&busquedaPorArtista $=146$

Iz modernistične tradicije, ki jo je sprožil Rdeči atelje, so črpali tudi slovenski slikarji in ustvarili številne mojstrovine. Te so zunaj slovenskega oziroma bivšega jugoslovanskega prostora kljub svoji nesporni kvaliteti ostale prezrte in niso bile vključene $\mathrm{v}$ zahodno umetnostnozgodovinsko dediščino. Med slovenskimi modernisti je svoj atelje najpogosteje upoda-

13 http://www.guggenheim-bilbao.es/secciones/la_coleccion/nombre_obra_descripcion. php?idioma=en\&id_obra=59\&anterior=buscar_obra\&busquedaPorArtista=146\&id_coleccion $<27.8 .2009>$. 
bljal Gabrijel Stupica, v čemer se je izmojstril in ustvaril nedosegljiv vzor, ki ga ni presegel noben slikar na ozemlju bivše Jugoslavije. Četudi se Stupica ni neposredno navezoval na Matissov Rdeči atelje, oba umetnika povezuje dejstvo, da sta šele z upodobitvijo resničnega ateljeja kot dvodimenzionalnega prostora odločno vstopila v modernizem (Mikuž, 1993, 20).

Prvo Stupičevo ustvarjalno obdobje je trajalo do leta 1954 in bi ga lahko označili kot problematiziranje realizma. Slikar se je vedno bolj oddaljeval od objektivnega podajanja resničnosti in se začel približevati subjektivnemu videnju figure, predmeta in prostora. Deklica v ateljeju (1953-54, Beograd, Muzej savremene umetnosti) pomeni skrajno stopnjo problematizacije realističnih načel, ki se kaže z zapiranjem prostora in iskanjem bistva oblik, kar nakazuje prehod v naslednje razdobje (Mikuž, 1995, 70-71). Glavni lik na sliki je malo rdečelaso bitje, ki z rokami v naročju neokretno sedi pred slikarjem, ki je potisnjen iz sredine. Vse je tako, kot je bilo v resnici, ob največji svetlobi najgloblja tema, in šele ko se oko privadi, se iz mraka trgajo na zid obešene in ob steno prislonjene podobe, slikarsko stojalo in druge, komaj razpoznavne oblike $\mathrm{v}$ ateljeju (Menaše in Menaše, 1984, 145).

Med letoma 1954 in 1958 je Stupica prišel do shematizacije predmetnih oblik in človeškega obraza ter opustil za zagrebško pred- in medvojno slikarstvo značilne temne tone. Vrhunec tega obdobja zaznamuje Avtoportret s hčerko (1956, Ljubljana, Moderna galerija). Avtor stoji v ateljeju, na kar kažejo njegova $\mathrm{z}$ barvami popackana obleka, paleta v levici in skice na steni v ozadju. Slikarjeva figura sega od zgornjega do spodnjega roba, s čimer je Stupica dosegel svojsko monumentalnost. Upodobljenčeve desne noge se deklica oklepa z velikimi temnimi očmi. Vendar figuri ne dajeta občutka telesne voluminoznosti, temveč delujeta kot prikazni, in čeprav sta postavljeni na trdna tla, se zdi, da lebdita v prostoru. Barvni madeži na slikarjevi obleki, ki žarijo kot kosci oglja ali kot drago kamenje, predirajo temino. Tako so se barve spremenile v edino svetlobo, ki ožarja umetnikov svet.

Februarja 1959 se je Stupica iz temačnega ateljeja na Resljevi cesti preselil v namensko grajeni atelje na Večni poti s severno lučjo. Istega leta je nastal Veliki avtoportret (Ljubljana, Moderna galerija) in ga lahko razumemo kot hommage novemu »razsvetljenju« (Mikuž, 1993, 27) oziroma novemu ateljeju. Pred nami je mogočna slikarjeva figura, ki se ji v levem zgornjem 
kotu približuje deklica - umetnikova hčerka. Slikar gleda predse v prostor, kot da ne bi opazil deklice, ki se kot angel ali muza spreletava okoli njegove glave. Podslikave kažejo, da je bila prvotno naslikana celopostavno in nižje, slikar pa se je s čopičem dotikal njene glave. Toda med slikanjem se mu je deklica izmuznila in poletela nad njegovo roko. Deklica se ozira proti gledalcu in steguje roko proti slikarju, pri čemer njena gesta spominja na angelski pozdrav, kot ga poznamo iz tradicije slikanja podob Oznanjenja. Iz dekličinih rok sevajo proti tlom trije dolgi žarki, ki spominjajo na noge slikarskega stojala. Stupica torej slika samega sebe, kako upodablja hčerko, svoj večni model, ki vodi njegovo roko pri slikanju. Avtorjeva roka se je ujela $\mathrm{v}$ žarke oziroma noge slikarskega stojala, ki gravitirajo proti tlom, podobno kot se barva cedi po umetnikovi delovni obleki. ${ }^{14}$

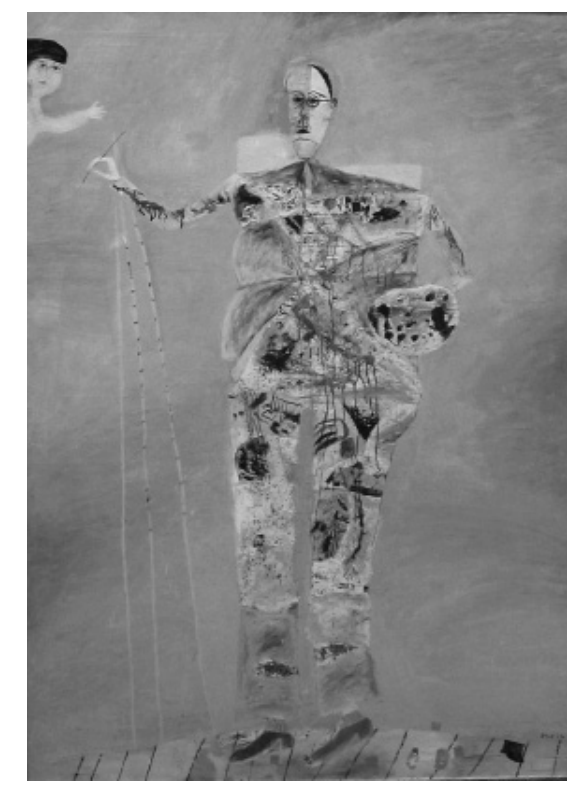

slika 8: Gabrijel Stupica, Veliki avtoportret, 1959, Moderna galerija, Ljubljana Vir: Mikuž (1993)

14 Mikuž pravi, da bi lahko Veliki avtoportret interpretirali kot sacra conversatione, nemi pogovor ustvarjalca s svojim angelom, inspirajočo muzo, z lastno dušo. Če je Gabrijel prišel Mariji oznanit vesel, a kar se da neverjeten in neprimerljiv dogodek brezmadežnega spočetja, je tu morda mala Marija, katere otroške risbe veliki slikar občuduje in na skrivaj posnema, prišla Gabrijelu oznanit skrivnost spočetja tistega, kar je za umetnika enako rojstvu otroka, se pravi umetniškega dela (Mikuž, 1993, 42). 
Naslednje Stupičevo razvojno obdobje se je začelo leta 1961 in je brez večjih premen trajalo do zadnjih del. Gre za obdobje belih slik, ki združujejo večino izkušenj njegovega dotedanjega ustvarjanja. Atelje II (1961, Beograd, Muzej savremene umetnosti) prekriva slikovita bela ploskev, ki zaznamuje belino ateljejskih sten. Daleč vsaksebi so slikarsko stojalo z ovalno podobo gospe, račun za porabljeni električni tok (št. 1044341, Stupica, cesta na Rožnik, očitno samo 333 starih dinarjev), onkraj črtkanih meja še neka gospa, v polju pod njo pod malim peščenim oblakom ali šopkom pa nevesta s pajčolanom in pred njo prtič (Menaše in Menaše, 1984, 154-155). Ti materialno otipljivi elementi enako kot pastozni nanosi in številni premazi učinkovito zaživijo v monokromiji, najbolj v belem enobarvju, kjer ni ekstremnih kontrastov, kjer se sence spreminjajo v svoje nasprotje, v neupodobljiv objekt. Čim bolj intimni so Stupičevi »tujki«, tem bolj resnični, reliefni in plastični si drznejo biti (Mikuž, 1993, 50).

Matissov Rdeči atelje je navdihoval tudi Marjana Dovjaka, ki je leta 1952 zaključil specialko pri Gabrijelu Stupici. Medtem ko je v petdesetih letih še ohranjal slikovitost figur in prostora, je v šestdesetih iluzijo globine opustil ter postopoma povsem prevzel ploskovito gradnjo slike, ki jo zaznamujejo gladke barvne površine. Posebnost Dovjakove likovne govorice so bile risarske intervencije, s čimer je ustvaril vtis nekakšne arabeske. Prostor, ki ga je upodabljal, je razložil v dve dimenziji. Interier je razprl kot škatlo, tako da so vse ravni, ki so prej omejevale prostor, ležale v eni ravnini. V tej ravnini pa so po umetnikovi logiki naseljeni predmeti bodisi lebdeli ali pa izgubljali telesnost in se spreminjali v ploskev (Sedej, 1985, 186-187).

Atelje I (1970, Ljubljana, Moderna galerija) odpira pogled v širok prostor, ki ga omejujejo bele stene, med katere so vpeta temnorjava tla. $\mathrm{Na}$ sredini spodnjega roba platna leži rdeča preproga s cvetličnim vzorcem, nad katero sta dve manjši preprogi s pikčastim vzorcem. Levo od preprog sedi na stolčku pritlikav slikar pred orjaškim slikarskim stojalom. Slikar se s čopičem dotika leve noge stojala, na katerem pa ni platna, zato se zdi, da polaga poteze v praznino pred seboj. Za stojalom je k steni prislonjena kmečka skrinja s floralnim vzorcem. V levem zgornjem kotu je kavč s pisano prevleko, v desnem zgornjem kotu pa ljudska plastika. Vzdolž desne stene sta postavljeni dve mizi. Na prvi leži mapa, na drugi pa tube z barvami. Tako kot na Rdečem ateljeju tudi na Ateljeju I na stenah visijo avtorjeva 
dela, med katerimi veliko modro platno na levi steni spominja na Matissovega Ikarja (1947). Četudi na Ateljeju I v primerjavi z Rdečim ateljejem ne prevladuje ena barva, obe sliki povezujejo izničenje prostorske globine, izkrivljeni proporci in dekorativne poenostavitve.

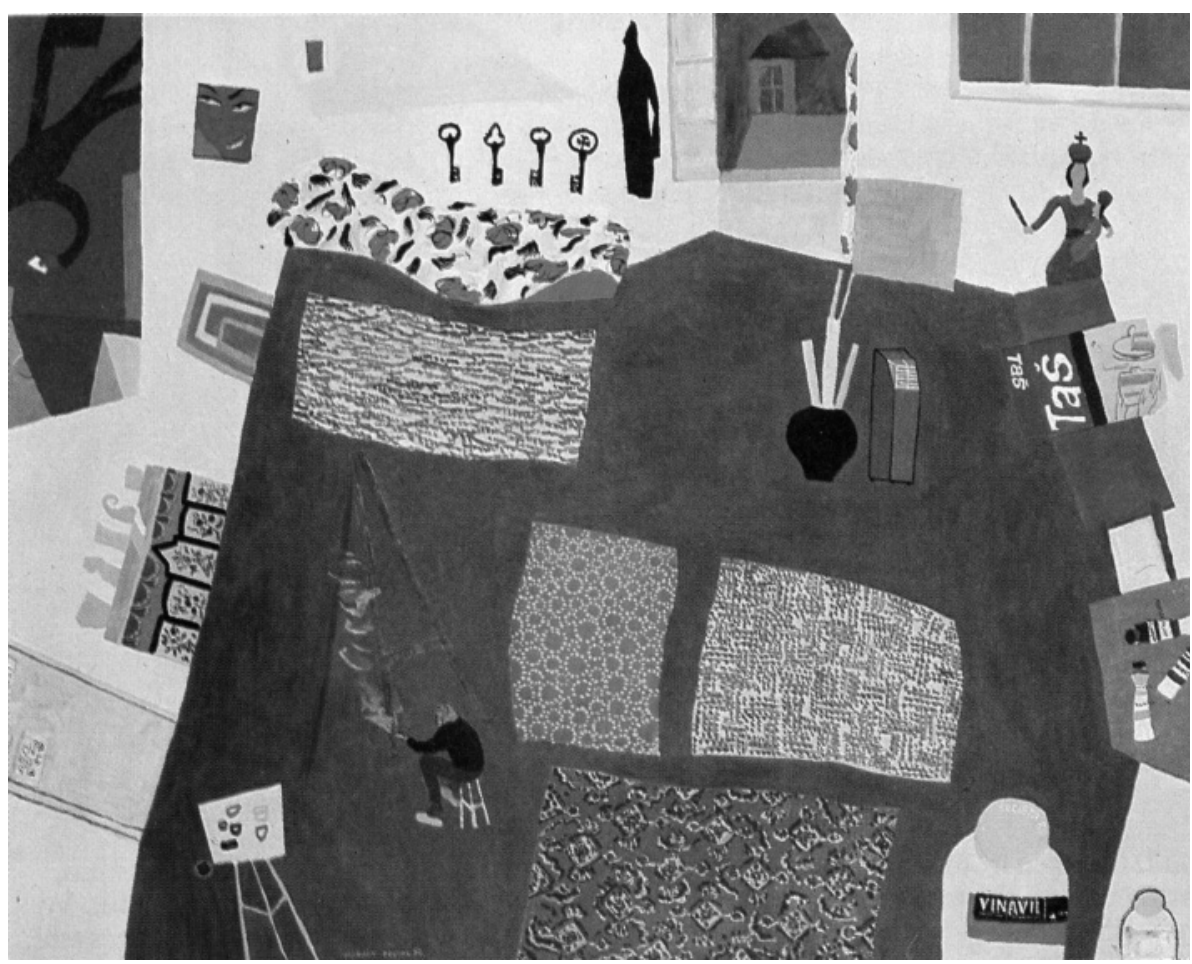

slika 9: Marjan Dovjak, Atelje I, 1970, Moderna galerija, Ljubljana Vir: Sedej (1985)

Specialko je skupaj z Marjanom Dovjakom in Aleksom Horvatom pri Gabrijelu Stupici vpisal Bogdan Borčič, čeprav jo je po prvem semestru sporazumno s profesorjem prekinil, saj je bil učiteljev vpliv premočan (Makuc, 2003, 206). Borčič je svoje vzornike razdelil na dva enakovredna pola. Na eni strani so tisti, s katerimi je živel, se učil in se oblikoval, na drugi pa tisti, $s$ katerimi se je srečeval v galerijah in muzejih v tujini. Silno je spoštoval slikarstvo Marka Šušteršiča, kar je mogoče opaziti pri podobni obravnavi rdeče barve pri obeh umetnikih, in Marjana Dovjaka, ker je opustil perspektivo 
in svoje interierje naslikal na talni ploskvi. Pri Henriju Matissu ga je očaralo, da napak ni brisal, popravljal ali skrival, temveč je novo potezo izvedel tako prepričljivo, da je prejšnja izgubila svojo moč in sporočilnost. Poleg tega ga je prevzela Matissova osnovna ploskev, ki jo opredeljuje ena sama barva, in čeprav je na njej predmetnost, se vedno bolj izgublja, izginja. Leta 1956 je Borčič prvič potoval $\mathrm{v}$ tujino, kjer se je na razstavi v Benetkah navdušil nad deli Marka Rothka. Z večletnim študijem je poskušal prodreti v Rothkov koncept: dvo- ali triplastnost, stopnjevanje barve, poenostavitev in napolnitev ploskve z energijo brez kakršnih koli asociacij na predmetnost. Matissove slike še premorejo drobec zgodbe, ki jo je Rothko povsem zanemaril, čeprav je Borčiča pri obeh najbolj fascinirala barva. Na koncu Borčičevih iskanj in srečanj z modernisti je bil Barnett Newman, pri katerem so mu bila blizu rdeča polja in monokromnost (Makuc, 2003, 208-210).

Borčič slika v ciklih, s katerimi se ukvarja tako dolgo, dokler ga zanimajo oziroma dokler kompozicijskega koncepta ne razvije do stopnje, ko začuti zadovoljstvo (Makuc, 2003, 214). Takšna občutja preplavljajo tudi gledalca ob Ateljejih, ki jih je Borčič začel snovati leta 1998. Podobno kot njegovi vzorniki se je zaprl $\mathrm{v}$ svojo delavnico in začel popisovati njen inventar. V kompozicijah, sestavljenih iz kvadratov, pravokotnikov in trikotnikov, prepoznamo profil stola, mize, slikarskega stojala in ravnila. Pri tem so nam v oporo naslovi, in četudi niso percepcijsko zavezujoči, bi bile slike brez njih samo abstraktne kompozicije likovnih znakov na slikovnem polju. Predvsem pa se je Borčič s ciklom Ateljejev priklonil slikarjem, ki so ga navdihovali in ga še navdihujejo pri njegovem ustvarjanju.

Rdeči atelje (1999, Slovenj Gradec, Koroška galerija likovnih umetnosti) je daljna reminiscenca Matissovega Rdečega ateljeja in nam hkrati v spomin prikliče Borčičevo Rdečo sliko iz leta 1986. Vsem trem slikam je skupna rdeča osnovna ploskev, ki jo na obeh Borčičevih slikah črna črta razpolavlja na dva pravokotnika. Če je slikar za svojo izpoved na Rdeči sliki potreboval samo rdečo barvo, je na Rdečem ateljeju dodal še rumen in zelen pravokotnik, ki aludirata na slike in pohištvo na Matissovi upodobitvi. Tako je Borčič nadgradil tradicijo (rdeče) monokromne osnovne ploskve, s katero je Matisse revolucioniral moderno umetnost ter vplival na Rothka in Newmana. 


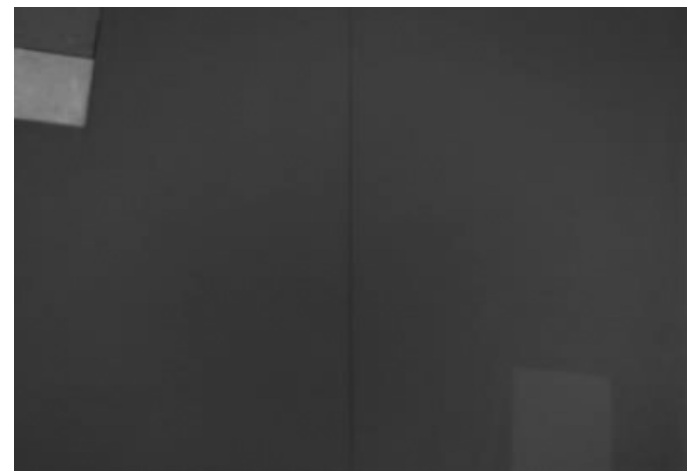

slika 10: Bogdan Borčič, Rdeči atelje, 1999, Koroška galerija likovnih umetnosti, Slovenj Gradec Vir: http://www.glu-sg.si/zbirke_kglu/index.html

$\mathrm{Na}$ številnih slikah iz cikla Ateljejev se je Borčič osredotočil samo na en predmet iz ateljeja. Največkrat je slikal stole, ki jih je iz navpičnih in vodoravnih pravokotnikov sestavil tako, da tvorijo profil stola. Vendar stol ni vedno postavljen pravokotno na spodnji rob platna, temveč ga je, kot se zdi na sliki Stol (1998, Slovenj Gradec, Koroška galerija likovnih umetnosti), slikar privzdignil oziroma upodobil v trenutku padanja proti tlom. Avtor je stol vpel med gladke in slikovite ploskve, medtem ko je Rdeči stol (1999, zasebna zbirka) izoblikoval z lazurnimi nanosi rdeče barve, skozi katero proseva črna podslikava, in ga prislonil na skrajni desni rob platna.

Slikarsko stojalo ali »štafelaj« je poleg čopičev in palete najpomembnejši slikarjev pripomoček, ki ga najdemo v vsakem ateljeju. Na njem sloni platno, na katerega slika umetnik, torej se na njem rojeva umetnina, zato ne preseneča, da srečamo motiv štafelaja tudi na Borčičevih delih. Čeprav se je Borčič pri slikarskih stojalih odločil za frontalen pogled, se Štafelaj II (2001) formalno navezuje na Rdeči stol. Črna podsnova preseva skozi rdečo osnovo. Na tej so v odtenek svetlejši rdeči barvi enakomerno izrisani dva daljša in krajši navpični trak ter prečni trak, ki zaznamujejo dele slikarskega stojala. Avtor je pri Štafelaju II ubral obratno pot kot pri Rdečem stolu, saj je naslikal manj slikoviti predmet na zelo slikoviti podlagi.

Motiv ateljeja je bil nedvomno osrednja tema v Matissovem opusu, saj mu je nudila največ možnosti za samorefleksijo. V fauvističnem in ekspe- 
rimentalnem obdobju je raziskoval atelje brez figur, torej ateljejski inventar, medtem ko ga je v Nici zanimal odnos med (namišljenim) slikarjem, modelom in gledalcem. Največja mojstrovina med Matissovimi ateljeji je Rdeči atelje, kar potrjuje njegov vpliv na slikarje v drugi polovici 20. stoletja. $\mathrm{V}$ Ameriki so se ob njem navdihovali slikarji barvnega polja. Gabrijel Stupica se ni neposredno navezoval na Rdeči atelje, temveč ga z Matissom povezuje dejstvo, da je šele $z$ upodobitvijo resničnega ateljeja kot dvodimenzionalnega prostora odločno stopil v modernizem. Marjan Dovjak je na svojih ateljejskih interierjih pokazal podoben smisel za izničenje prostorske globine, izkrivljene proporce in dekorativne poenostavitve kot Matisse pri Rdečem ateljeju. Nazadnje se je s svojimi slikami ateljejev Matissovi mojstrovini priklonil Bogdan Borčič. Pregled motiva slikarjevega ateljeja pri ameriških in slovenskih slikarjih je pokazal, da je Rdeči atelje ohranil inspirativno moč za umetnike vse do danes, zato bo za raziskovalce zanimiv tudi v prihodnosti.

\section{LITERATURA}

Ashton, D., About Rothko, New York, 1983.

Bauer, I., Das Atelierbild in der französischen Malerei: 1855-1900, Köln, 1999.

Breslin, J. E. B., Mark Rothko, a Biography, Chicago-London, 1993.

Elderfield, J., Henri Matisse, A Retrospective, The Museum of Modern Art, New York, 1992.

Flam, J. D., Einleitung, Henri Matisse: Über Kunst (ed. Jack. D. Flam), Zürich, 1982.

Flam, J. D., Henri Matisse 1869-1954, Köln, 1994.

Fourcade, D., Henri Matisse, Ecrits et propos sur l'art, Pariz, 1972.

Greenberg, C., The collected essays and criticism (ed. John O'Brien), Chicago-London, 1986.

Greenberg, C., Henri Matisse, New York, 1953. 
Jacobus, J., Henri Matisse, New York, 1980.

Kosténévich, A. in Sémionova, N., Matisse et la Russie, Pariz, 1993.

MacCheseny, C. T., Ein Gespräch mit Matisse, Henri Matisse: Über Kunst (ed. Jack. D. Flam), Zürich, 1982.

Makuc, A., Bogdan Borčič z Andrejem Makucem o slikarstvu, Bogdan Borčič: Slike, Slovenj Gradec, 2003.

Menaše, Luc in Ljerka, Med ljudmi in spomeniki, Trst, 1984.

Mikuž, J., Gabrijel Stupica: 1913-1990, Ljubljana, 1993.

Mikuž, J., Gabrijel Stupica, eksistencialistična umetnost in art brut, Slovenska moderna umetnost in zahodna umetnost: od preloma s socialističnim realizmom do konceptualizma, Ljubljana, 1995.

Schnell, W., Das rote Atelier des Henri Matisse - ein Bild und seine Verwandten, Berlin, 2001.

Sedej, I., Sto znanih slovenskih umetniških slik, Ljubljana, 1985.

Spurling, H., How Matisse became a painter, The Burlington Magazine, Vol. 135, No. 1084 (Jul., 1993), str. 463-470.

Trapp, F. A., The Atelier Gustave Moreau, Art Journal, Vol. 22, No. 2 (Zima 1962-1963), str. 92-95.

http://www.guggenheim-bilbao.es/secciones/la_coleccion/nombre_ obra_descripcion.php?idioma $=$ en\&id_obra $=59$ \&anterior $=$ buscar obra\&busquedaPorArtista=146\&id_coleccion $=$

http://www.nationalgalleries.org/index.php/collection/online_az/4:322/ results/0/694/ 


\section{THE STUDIO MOTIF IN HENRI MATISSE'S PAINTINGS AND THE INFLUENCE OF THE RED STUDIO ON PAINTERS OF THE SECOND HALF OF THE TWENTIETH CENTURY}

Keywords: studio motif, Henri Matisse, Color Field painters, Gabrijel Stupica, Marjan Dovjak, Bogdan Borčič

\section{Abstract}

The studio motif was the central iconographic theme in Matisse's oeuvre because it gave him the opportunity for introspection. In his fauve and experimental period, Matisse painted the studio without figures (the studio inventory itself), whereas in Nice he was interested in the relation between the (imaginary) painter, the model, and the beholder in the studio. The greatest masterpiece of all of Matisse's studio pictures is undisputedly The Red Studio (1911, New York, The Museum of Modern Art), which represents a defining moment in European modernism because of its formal radicalism. No painter before that time had reduced a picture of such large format to a single color. Matisse's intention was not to paint a picture of a real studio interior, but to create a painted equivalent of his emotional experience of his studio. With intense and evenly spread red paint, Matisse achieved a completely flat picture plane, thereby illustrating the idea of the spatial depth of the studio with the addition of easels, pictures, and sculptures. Matisse thus achieved something that seemed impossible: a flat impression of a picture that at the same time offers the feeling of space.

With his The Red Studio, Matisse not only broke with tradition, but established a basis for a new tradition. The Red Studio has hung in The Museum of Modern Art in New York since 1949 and has become one of the most influential paintings of the twentieth century. It inspired the Color Field painters Mark Rothko, Barnett Newmann, and Robert Motherwell. Some Slovenian painters also looked to The Red Studio and created several masterpieces. In spite of their quality, they were overlooked outside Slovenia and the former Yugoslavia, and were excluded from European art heritage. 
The most prominent Slovenian modernist painter, Gabrijel Stupica, did not directly rely on The Red Studio, but is linked with Matisse because of the fact that Stupica entered into modernism only with his picture of the studio as a two-dimensional space. In his pictures of studio interiors, Marjan Dovjak showed a sense for ignoring the depth of space, distorted proportions, and decorative forms similar to Matisse in The Red Studio. Bogdan Borčič also paid homage to Matisse's masterpiece with his great monochrome pictures of studios. An examination of the studio motif by American and Slovene painters therefore shows that The Red Studio has preserved its inspirational power to today and will therefore remain an interesting topic for future researchers. 